Our Nature 2013, 11(2): 152-167

\title{
Distribution and Conservation of Less Known Rare and Threatened Plant Species in Kachchh, Gujarat, India
}

\author{
Pankaj N. Joshi ${ }^{1}$, Hiren B. Soni ${ }^{2}$, S.F. Wesley Sunderraj ${ }^{3}$ and \\ Justus Joshua ${ }^{4}$ \\ ${ }^{1}$ Sahjeevan, Hospital Road, Bhuj (Kachchh) - 370001 (Gujarat), India \\ ${ }^{2}$ P.G. Department of Environmental Science and Technology (EST) \\ Institute of Science and Technology for Advanced Studies and Research (ISTAR) Vallabh Vidyanagar - 388120 \\ (Gujarat), India \\ ${ }^{3}$ Green Future Foundation, 5-10/H, Madhav Residency, Opp. Kachchh University, \\ Mundra Road, Bhuj (Kachchh) - 370001 (Gujarat), India \\ ${ }^{4}$ Green Future Foundation, 45, Modern Complex, Bhuwana, Udaipur - 313001 (Rajasthan) India \\ Corresponding Author: drhirenbsoni@gmail.com
}

Received: 01.08.2013; Accepted: 09.11.2013

\begin{abstract}
The present survey was conducted in different terrains, habitats and ecosystems of Kachchh, Gujarat, India, for consecutive 3 years (2001-2002) in all possible climatic seasons, to know the present status of 6 less known rare and threatened plant species viz., Ammannia desertorum, Corallocarpus conocarpus, Dactyliandra welwitschii, Limonium stocksii, Schweinfurthia papilionacea and Tribulus rajasthanensis. Distribution, abundance and population dynamics of these species were derived.
\end{abstract}

Key words: Ammannia desertorum, rare plant, abundance, population dynamic, arid zone

\section{Introduction}

The arid zone in India is $3,20,000 \mathrm{~km}^{2}$ of which $62,180 \mathrm{~km}^{2}$ is located in the Gujarat State and $73 \%$ arid area of the Gujarat State lies in Kachchh district. Kachchh is a land abundant region covering $23 \%$ of the northwest part of the Gujarat state, and the largest district of the Gujarat State.

The earlier published reports by Palin (1880), Blatter (1908), Cooke (1908, 1958, 1967), Blatter and Hallberg (1918, 1984), Saxton and Sedgwick (1918), Pandey et al. (1983) and Anon (1982, 1994) do not describe all rare plant species of the district. Some detailed investigation on the vegetation of Kachchh and neighboring areas were investigated only after late 1930 (Thaker, 1926; Cooke, 1958; Santapau,
1962; Puri et al., 1964; Patel, 1971; Bhandari, 1978, 1990; Shah, 1978; Shetty and Singh, 1988) and detailed study on threatened plant species of Kachchh remain more or less unexplored.

\section{Materials and methods}

Based on the secondary information, the survey was conducted in Kachchh Desert Island, Gujarat, India, for 3 consecutive years (2001 to 2003). In addition, adjoining areas which had similar habitat types were also searched. The reported areas were identified on 1:50,000 or 1:2,50,000 scaled toposheets (FSI, 2002) (Fig. 1).

In the present study, in total 20 different plant species listed as rare and 


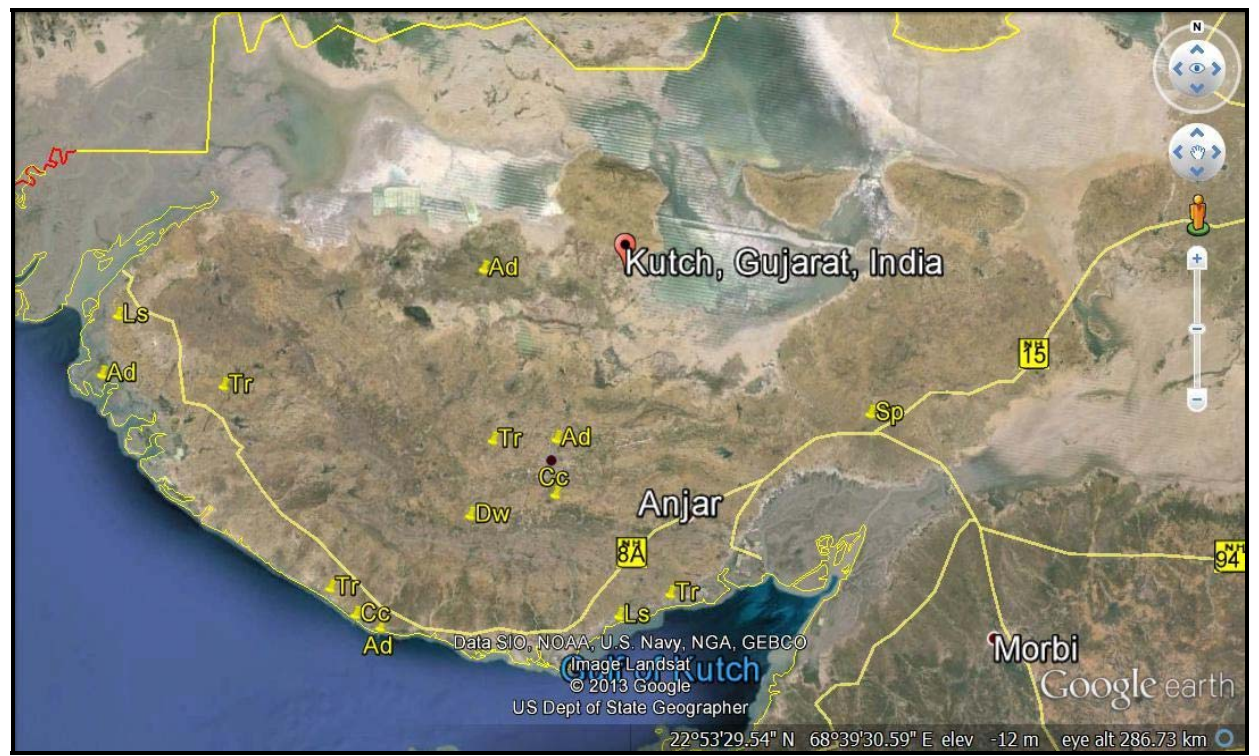

Figure 1. Map showing distribution of 6 rare plant species in Kachchh $(\mathrm{Ad}=$ Ammannia desertorum, $\mathrm{Cc}=$ Corallocarpus conocarpus, Dw = Dactyliandra welwitschii, $\mathrm{Ls}=$ Limonium stocksii, $\mathrm{Sp}=$ Schweinfurthia papilionacea, $\mathrm{Tr}=$ Tribulus rajasthanensis)

endangered belonging to different forms like shrubs, undershrubs, herbs and pseudobulbs were selected. After reaching to the initial point, belts transect of $5 \mathrm{~m}$ width and length extending to the entire width of the patch was laid. Within this belt, speciesspecific search was carried out, and once a target species was located a species centered circular plot of $5 \mathrm{~m}$ radius for shrubs and 12 m radius for herbs were laid (Greig-Smith, 1964). In these plots, number of individuals of the target species, associated species, regeneration (if any) alongwith habitat and environmental parameters were recorded. Where the plant was located, search for the species was carried out in 6 directions (2 major and 4 minor, leaving the direction of the transect), along a belt of $3 \mathrm{~m}$ wide and $10 \mathrm{~m}$ long for herbs, and length of $30 \mathrm{~m}$ for shrubs. If the plant was encountered, then the maximum distance would extend up to $100 \mathrm{~m}$. For each individual plant, the habitat and environmental parameters were documented (Barbour et al., 1987).

In case of abundant targeted species, the systematic sampling was used. Depending on the spread or distribution or occurrence of the species, a circular plot of $5 \mathrm{~m}$ radius for shrub and $2 \mathrm{~m}$ for herb was laid at every 100 to $200 \mathrm{~m}$ distance. An intensive search was made to look for similar types of microhabitats in and around the targeted species. For every species and individuals located, the same information was recorded. In case of microhabitats like damp places or aquatic bodies, a belt transect of $2 \mathrm{~m}$ width for herbs and $5 \mathrm{~m}$ width for shrubs was laid along the edges of the water body. In case of abundant plant species, belt transects radiating from the edge of the aquatic body on 8 directions were laid to assess the numbers and the extent of their spreading from the main microhabitat (Hill et al., 2005). Along these belts, if a plant was located then a group- 
specific species-centered plot was laid to record all other parameters. In case of species occurring in coastal areas, belt transects (group-dependant width), parallel to coastline, radiating from the coastline, towards the land-slope was laid, and when a targeted species was encountered a speciescentered circular plot (5 $\mathrm{m}$ radius for shrubs and $2 \mathrm{~m}$ radius for herbs) was laid to document all useful and existing parameters (Simpson, 1949; Kalra and Maynard, 1991; Matthew and Aller, 1993). In general, the broad-spectrum of quantitative ecology of vegetation was considered for employing the suitable methods (Phillips, 1959).

\section{Results and discussion}

In total, 28 locations were surveyed for less known rare and threatened plant species. Of the surveyed areas, the studied plant species were located in 26 (92.86\%) other habitats, followed by 1 (3.57\%) protected area and reserve forest, each (Tab. 1). The area surveyed during the present investigation was 137 ha, of which 72 ha (52.55\%) area was found to harbour higher population of Tribulus rajasthanensis, followed by moderate numbers of Ammannia desertorum in 36 ha (26.28\%), considerable population of Dactyliandra welwitschii in 20 ha (14.60\%), lower numbers of Corallocarpus conocarpus and Limonium stocksii in 4 ha (2.92\%) each, and the least population of Schweinfurthia papilionacea in only 1 ha $(0.73 \%)$. The similar results were obtained in case of number of sampled units (ha) for respective species (Tab. 2). Of the surveyed area (28), 16 (57.14\%) areas were found to harbour a good population of T. rajasthanensis, followed by $4(14.29 \%)$ locations with considerable population of $D$. welwitschii, $3(10.71 \%)$ localities with $C$. conocarpus, 2 (7.14\%) areas with $A$. desertorum and $L$. stocksii, each, and only 1 (3.57\%) region with S. papilionacea (Tab. $3)$.

Of the total 1673 individuals of rare and threatened plants, 1071 (64.02\%) individuals of $T$. rajasthanensis, followed by 405 (24.21\%) L. stocksii, 136 (8.13\%) S. papilionacea, 38 (2.27\%) D. welwitschii, 16 $(0.96 \%) \quad A$ desertorum, and the least individuals $7(0.42 \%)$ of $C$. conocarpus, were observed (Tab. 1, Figs. 2, 3). Of the reported species, $S$. papilionacea exhibited maximum density (95.83/ha), followed by 95.52/ha of $L$. stocksii, T. rajasthanensis (23.49/ha), D. welwitschii (1.90/ha), C. conocarpus (1.75/ha), and the lease density was reprinted by $A$. desertorum (0.44/ha) (Tab. 2, Fig. 4).

\section{Ammannia desertorum Blatt. and Hall. (Lythraceae)}

An erect herb (Blatter and Hallberg, 1918; Shah, 1978), rigid, coarse, more or less scabrous, pappilose and up to $50 \mathrm{~cm}$ high twiner, locally called Jalbhangra in Rajputana (Blatter and Hallberg, 1918), Moto Jal Bhangro in Marwari (Nayar and Shastri, 1988), and Moto Jaal Bhangro in Rajasthani (Bhandari, 1990).

The plant has been reported from Jodhpur, Jaisalmer, Devikot in Rajasthan and Gujarat in India and Sind in Pakistan (Santapau, 1962). Blatter and Hallberg (1918) collected the holotype from Rajasthan in 1917. It is distributed in Rozi (in dried-up pool in fruiting stage) Saurashtra (Santapau, 1962), Baroda and Bharuch (Shah, 1978), Jamnagar (Santapau, 1962; Nayar and Sastry, 1988), Panchamahals (Bhatt, 1975), Vadapada (Vashi, 1985) and Karvad (Contractor, 1986). 
Pankaj N. Joshi, Hiren B. Soni, S.F. Wesley Sunderraj and Justus Joshua/ Our Nature (2013), 11(2): 152-167

Table 1. Abundance of threatened plant species in Kachchh.

\begin{tabular}{|c|c|c|c|c|c|c|c|c|}
\hline \multirow{2}{*}{ Species } & \multicolumn{3}{|c|}{ No. of Locations } & \multirow{2}{*}{-Total } & \multicolumn{3}{|c|}{ Abundance } & \multirow{2}{*}{-Total } \\
\hline & $\overline{\mathbf{P A}}$ & RF & Others & & $\overline{\mathbf{P A}}$ & RF & Others & \\
\hline Ammannia desertorum & 0 & 0 & 2 & 2 & 0 & 0 & 16 & 16 \\
\hline Corallocarpus conocarpus & 0 & 0 & 3 & 3 & 0 & 0 & 7 & 7 \\
\hline Dactyliandra welwitschii & 0 & 0 & 4 & 4 & 0 & 0 & 38 & 38 \\
\hline Limonium stocksii & 0 & 0 & 2 & 2 & 0 & 0 & 405 & 405 \\
\hline Schweinfurthia papilionacea & 0 & 0 & 1 & 1 & 0 & 0 & 136 & 136 \\
\hline Tribulus rajasthanensis & 1 & 1 & 14 & 16 & 37 & 6 & 1028 & 1071 \\
\hline Total & 1 & 1 & 26 & 28 & 37 & 6 & 1630 & 1673 \\
\hline$\%$ & 3.57 & 3.57 & 92.86 & 100.00 & 2.21 & 0.36 & 97.43 & 100.00 \\
\hline
\end{tabular}

$\mathrm{PA}=$ Protected area, $\mathrm{RF}=$ Reserve forest

Table 2. Population dynamics of threatened plant species in Kachchh.

\begin{tabular}{lccccc}
\hline \multicolumn{1}{c}{ Species } & A & B & C & D & E \\
\hline \multirow{2}{*}{ Ammannia desertorum } & Others & 36 & 36.18 & 16 & 0.44 \\
& Total & 36 & 36.18 & 16 & 0.44 \\
\hline \multirow{2}{*}{ Corallocarpus conocarpus } & Others & 4.00 & 4.00 & 7 & 1.75 \\
& Total & 4.00 & 4.00 & 7 & 1.75 \\
\hline \multirow{2}{*}{ Dactyliandra welwitschii } & Others & 20 & 20 & 38 & 1.90 \\
& Total & 20 & 20 & 38 & 1.90 \\
\hline \multirow{2}{*}{ Limonium stocksii } & Others & 4.00 & 4.24 & 405 & 95.52 \\
& Total & 4.00 & 4.24 & 405 & 95.52 \\
\hline \multirow{2}{*}{ Schweinfurthia papilionacea } & Others & 1.0 & 1.4 & 136 & 95.83 \\
& Total & 1.0 & 1.4 & 136 & 95.83 \\
\hline \multirow{2}{*}{ Tribulus rajasthanensis } & PA & 6.00 & 6.06 & 37 & 6.11 \\
& RF & 4.00 & 4.00 & 6 & 1.50 \\
& Others & 62.00 & 64.70 & 1028 & 15.88 \\
\hline \multirow{2}{*}{ A } & Total & 72.00 & 74.76 & 1071 & 14.33 \\
\hline
\end{tabular}

$\mathrm{A}=$ Status of protection, $\mathrm{B}=$ Area surveyed (ha), $\mathrm{C}=$ No. of sampled units (ha), D = Abundance, E = Density/ha

Table 3. Locations of Threatened Plant Species in Kachchh

\begin{tabular}{|c|c|c|c|c|c|c|}
\hline Species & Taluka & Location & $\mathbf{A}$ & $\mathbf{B}$ & C & $\mathbf{D}$ \\
\hline \multirow{4}{*}{ Ammannia desertorum } & Bhuj & Bhirandiyara, Khawda & 15.0 & 15.06 & 4 & 0.27 \\
\hline & Naliya & Jakhau & 20.0 & 20.06 & 3 & 0.15 \\
\hline & Naliya & Jakhau & 1.0 & 1.06 & 9 & 8.49 \\
\hline & & Total & 36 & 36.18 & 16 & 0.44 \\
\hline \multirow{4}{*}{$\begin{array}{l}\text { Corallocarpus } \\
\text { conocarpus }\end{array}$} & Bhuj & Sural Pith, Bhuj & 1.00 & 1.00 & 2 & 2.00 \\
\hline & Bhuj & Wadasar & 1.00 & 1.00 & 2 & 2.00 \\
\hline & Mandvi & Tregdi & 2.00 & 2.00 & 3 & 1.50 \\
\hline & & Total & 4 & 4 & 7 & 1.75 \\
\hline \multirow{5}{*}{ Dactyliandra welwitschii } & Bhuj & Chundri & 4.0 & 4.0 & 2 & 0.5 \\
\hline & Bhuj & Dhoravar & 10.0 & 10.0 & 32 & 3.2 \\
\hline & Bhuj & Gajod & 5.0 & 5.0 & 2 & 0.4 \\
\hline & Bhuj & Tuga & 1.0 & 1.0 & 2 & 2.0 \\
\hline & & Total & 20.0 & 20.0 & 38 & 1.9 \\
\hline \multirow{3}{*}{ Limonium stocksii } & Mundra & Bhadreshwar & 3 & 3.18 & 375 & 117.98 \\
\hline & Lakhpat & Guneri & 1 & 1.06 & 30 & 28.31 \\
\hline & & Total & 4 & 4.24 & 405 & 95.52 \\
\hline
\end{tabular}


Pankaj N. Joshi, Hiren B. Soni, S.F. Wesley Sunderraj and Justus Joshua/ Our Nature (2013), 11(2): 152-167

\begin{tabular}{lllcccc}
\hline Species & Taluka & Location & A & B & C & D \\
\hline $\begin{array}{l}\text { Schweinfurthia } \\
\text { papilionacea }\end{array}$ & Bhachau & Narmda Pipeline & 1.0 & 1.4 & 136 & 95.83 \\
\cline { 2 - 6 } & & Total & $\mathbf{1 . 0}$ & $\mathbf{1 . 4}$ & $\mathbf{1 3 6}$ & $\mathbf{9 5 . 8 3}$ \\
\hline & Bhuj & Meghapar & 2.00 & 2.00 & 4 & 2.00 \\
& Bhuj & Nr. Bharapar & 4.00 & 4.06 & 9 & 2.22 \\
& Bhuj & Dhunai & 4.00 & 4.00 & 7 & 1.75 \\
& Mandvi & Kera-Dahisar & 6.00 & 6.18 & 24 & 3.88 \\
& Mundra & Beraja & 1.00 & 1.06 & 5 & 4.72 \\
& Mundra & Navinal & 4.00 & 4.00 & 6 & 1.50 \\
& Mundra & Kalaghogha Bridge & 3.00 & 3.12 & 8 & 2.56 \\
& Naliya & Kalitalav & 10.00 & 10.30 & 60 & 5.83 \\
& Naliya & Khuada & 2.00 & 2.00 & 2 & 1.00 \\
& Naliya & Lala Budiya & 6.00 & 6.06 & 37 & 6.11 \\
& Naliya & Prajav & 4.00 & 4.06 & 23 & 5.67 \\
& Naliya & Rava & 2.00 & 2.00 & 5 & 2.50 \\
& Naliya & Vengaber & 6.00 & 6.54 & 218 & 33.34 \\
& Naliya & Air force & 3.00 & 3.24 & 168 & 51.86 \\
& Naliya & Air force & 3.00 & 3.18 & 46 & 14.47 \\
& Naliya & Prajav & 2.00 & 2.18 & 34 & 15.60 \\
& Naliya & Sindhrodi & 2.00 & 2.12 & 14 & 6.60 \\
& Naliya & Vengaber & 8.00 & 8.66 & 401 & 46.31 \\
\cline { 2 - 6 } & & Total & $\mathbf{7 2}$ & $\mathbf{7 4 . 7 6}$ & $\mathbf{1 0 7 1}$ & $\mathbf{2 3 . 4 9}$ \\
\hline
\end{tabular}

A = Area surveyed (ha), B = Sampled units (ha), C = Abundance, $\mathrm{D}$ = Density/ha

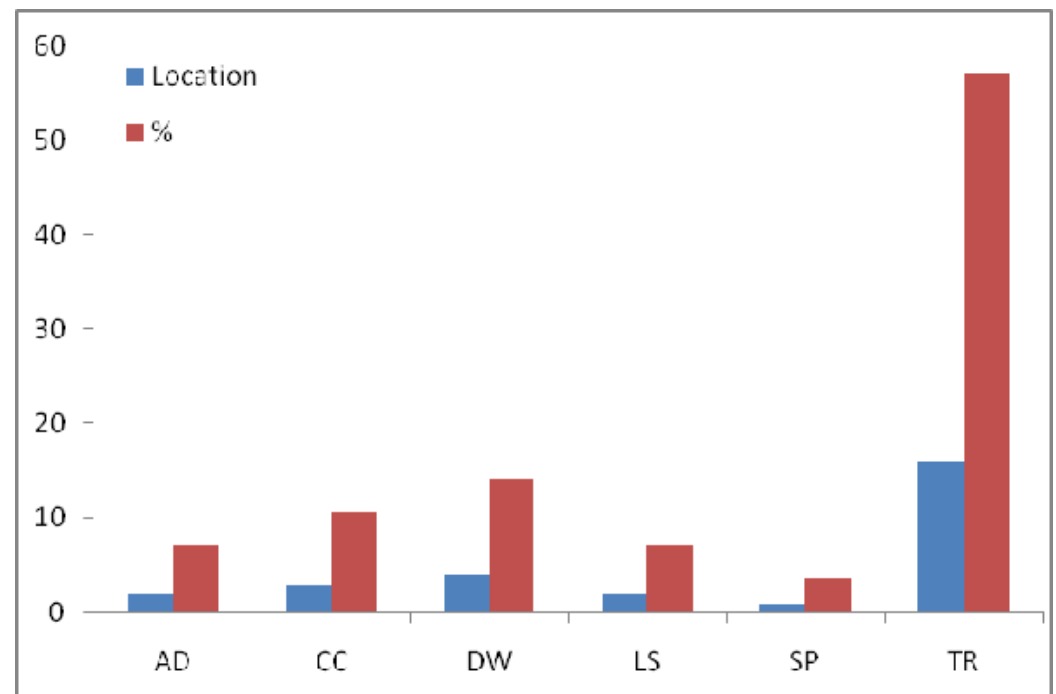

Figure 2. Distribution of rare and threatned plant species in Kachchh. $\mathrm{AD}=$ Ammannia desertorum, $\mathrm{CC}=$ Corallocarpus conocarpus, DW = Dactyliandra welwitschii, LS = Limonium stocksii, SP= Schweinfurthia papilionacea, $\mathrm{TR}=$ Tribulus rajasthanensis 
Pankaj N. Joshi, Hiren B. Soni, S.F. Wesley Sunderraj and Justus Joshua/ Our Nature (2013), 11(2): 152-167

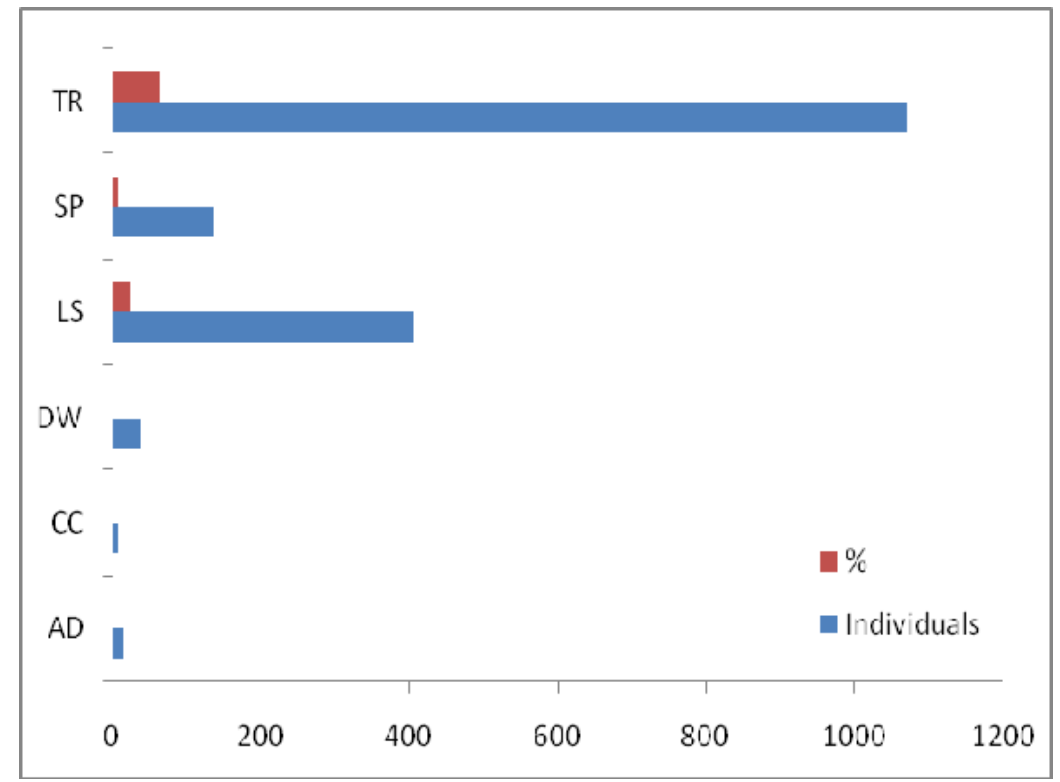

Figure 3. Abundance of rare and threatned plant species in Kachchh. $\mathrm{AD}=$ Ammannia desertorum, $\mathrm{CC}=$ Corallocarpus conocarpus, DW = Dactyliandra welwitschii, LS = Limonium stocksii, $\mathrm{SP}=$ Schweinfurthia papilionacea, $\mathrm{TR}=$ Tribulus rajasthanensis

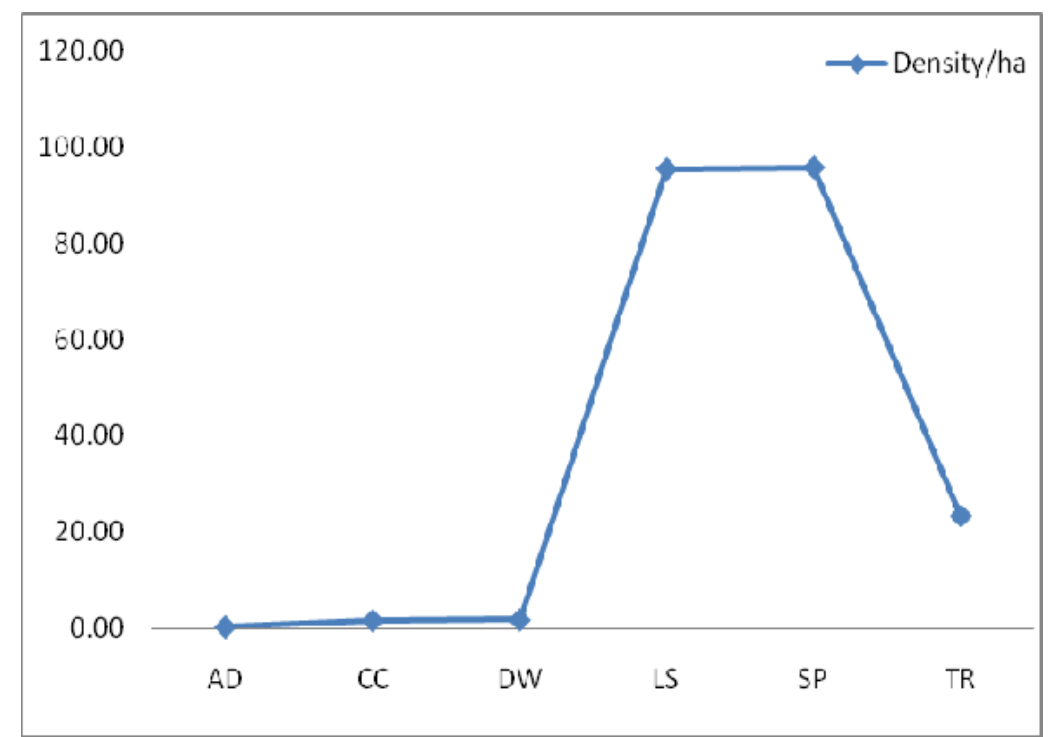

Figure 4. Density (per ha) of rare and threatned plant species in Kachchh. $\mathrm{AD}=$ Ammannia desertorum, $\mathrm{CC}=$ Corallocarpus conocarpus, DW = Dactyliandra welwitschii, LS = Limonium stocksii, SP= Schweinfurthia papilionacea, $\mathrm{TR}=$ Tribulus rajasthanensis 
During the present study, the plant was reported only from Bhuj and Naliya, the unprotected sites, from Kachchh. Santapau (1962) observed its fruiting only in October. Blatter and Hallberg (1984) observed its flowers and fruits during November, while Shah (1978) observed the same from October to December. But Nayar and Shastry (1988) observed its flowering from September to November. In the present study, this plant species was recorded with leaves, flowers and fruits during the month of August. This aspect of the study needs more detailed monitoring, which is essential for seed collection and investigating the natural regeneration ( $\mathrm{Pl} .1$ ).

A. desertorum was associated with 5 plant species viz., $48.15 \%$ with Scirpus and Cyperus spp., 22.22\% with A. baccifera and rests with Eclipta prostrate and Phyla nodiflora. It has been reported that this herb is usually found associated with $A$. baccifera, Cyperus sp. and Typha sp. (Nayar and Shastry, 1988). Thus, this species showed the strong affinity with its associated species. During the present study, the species was observed at the edge of the water near the banks alongwith the small brackish waterbodies. The plant prefers the swampy and wet areas. The species has been reported on wet grounds and marshy places (Contractor, 1986). The identification of potential sites along with the associated species can help in either locating the species or even selecting such sites for its reintroduction.

As per the observations made during the present survey in varied ecosystems, the plant was found to be very rare. The species was recorded in the wetland ecosystem along with 2 species of grass and herbs. The herb A. desertorum was located at the edge of the water on the soil substrate, which had sandy clay soil with moderate soil depth. The terrain of the surveyed site had gentle slope. This clearly shows that this species is habitat-specific.

During the survey, no any specific threat could be identified, but since it was found near the water there are chances of the plant getting destroyed by livestock either in the form of grazing or trampling (grazing was recorded on four occasions). In 5 individuals of the species, leaves and flowers were found to be affected by signs of an insect-bite, which could be another major threat in inhibiting its seed production, and may result into paucity of its regeneration capacity.

\section{Conservation measures recommended}

- Protection of its natural habitats and introduction of the plant into Botanical or Experimental gardens recommended by Nayar and Shastry (1988) should be followed immediately, which would aid in preserving the seed and genes both in in-situ and ex-situ conditions.

- Collection of seeds to study its viability, germination and plant growth is very essential to spell out proper strategies to substantiate the wild population.

- In-depth studies on the micro- and macro-habitats are very crucial, which are essential in propagating the plant in Botanical gardens. Such strategies could also form an important tool for identification of the reintroduction sites inside the protected areas.

- In addition to carrying out more intensive habitat-specific surveys in Kachchh, the plant species must be protected with the help of the locals by making them aware of its rarity. The two potential sites (viz., Bhuj and Naliya, where the plant was observed) 
can be kept out of grazing by the cattle with natural fencing. Moreover, grazing should be monitored by the local people on regular basis. This would ensure the long-term survival of this species in the wild.

- Effects and magnitudes of insect-attacks must be documented to mitigate the problem.

Corallocarpus conocarpus (Dalz. \& Gibs.) Hook. f. ex Clarke. (Cucurbitaceae)

It is a monoecious, slender and glabrous climbing herb, distributed in India, Sindh, Karachi and Tropical Africa. In India, it is distributed in Rajasthan (Pali, Sardarsamand) and Gujarat (Bhandari et al., 1996). Within Gujarat, it is found in Malpor and Gundar provinces (Cooke, 1908) and some regions of Kachchh (Bhandari et al., 1996). On the whole, this species was documented from three different locations of Kachchh.

The flowering season is during the months of June to August (Cooke, 1908). During this study, vegetative phase was observed from May to July. Flowering was recorded in June and August. It can be presumed to be available in July also. The fruiting was also noted during the same months (flowering months). Except leafy, fruiting and flowering phases, no other information exists on the other aspects of the phenology of this species.

A total of 14 species were found to be associated with $C$. conocarpus. It was associated frequently with Indigofera cordifolia (16.98\%), Dicanthium annulatum (16.98\%), Prosopis juliflora (13.21\%), Grewia tenax (11.32\%), Cymbopogon sp. (9.43\%) and Euphorbia nivulia (7.55\%) forming $75.47 \%$ of the total associations. The plant was documented mainly from forest ecosystem in mixed forest, more specifically in the forest patches along roadsides. The plant was predominantly found on moderately undulating terrain with moderate slopes. In the present study, it was found on the sandy soil substrate on the forest and fallow lands along roadsides (Pl. 1).

No potential threats were documented for this species as the number of individuals enumerated was very low. Being on the roadside and also a climbing herb, it can possibly get destroyed by road widening or cutting of host plant for fuelwood purpose.

\section{Conservation measures recommended}

- The sites where the species was sighted in protected area should be identified, and given strict protection. This would ensure safety to the species and also serve as natural gene and seed bank.

- The plant should be introduced into the Botanical gardens to ensure ex-situ conservation to preserve its germplasm.

- An in-depth systematic survey in the form of an ecological study covering various aspects of population dynamics, seed production, dispersing agents and habitat features are highly necessary for preparing proper ex-situ and in-situ conservation strategies.

- Creation of awareness among forest staff, local school teachers and students, and local farmers is very important as it would aid in mobilizing the peoples' support for conservation.

\section{Dactyliandra welwitschii Hook. F (Cucurbitaceae)}

It is a scabrid (Hook, 1871) or tendril climber (Shah, 1978) locally known as Ankhphutamani in Gujarat, and Badi Ankh Phootani Ki Bel in Hindi. The species is 
Pankaj N. Joshi, Hiren B. Soni, S.F. Wesley Sunderraj and Justus Joshua/ Our Nature (2013), 11(2): 152-167
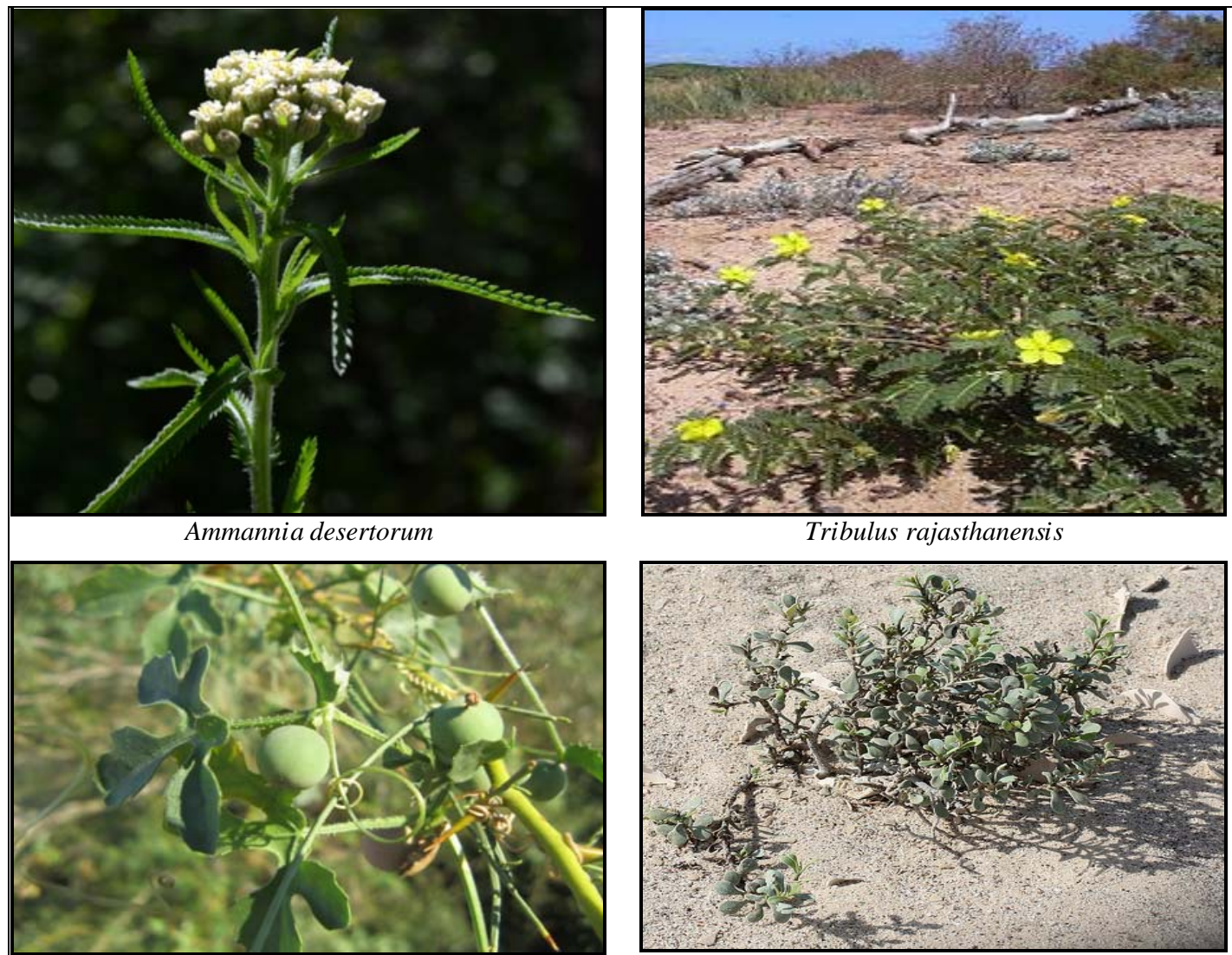

Tribulus rajasthanensis

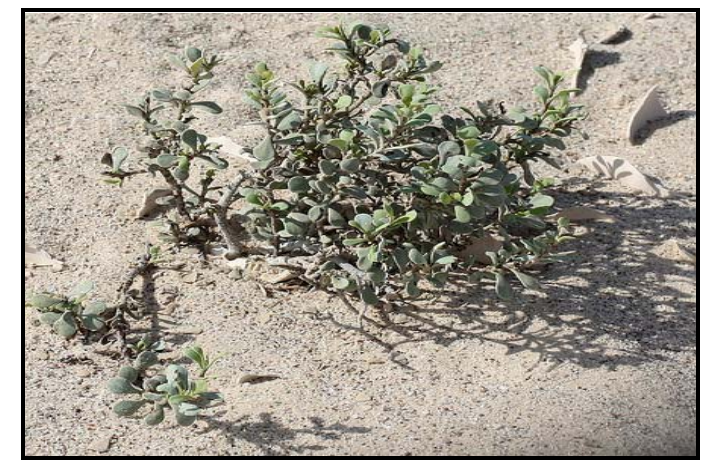

Dactyliandra welwitschii

Limonium stocksii

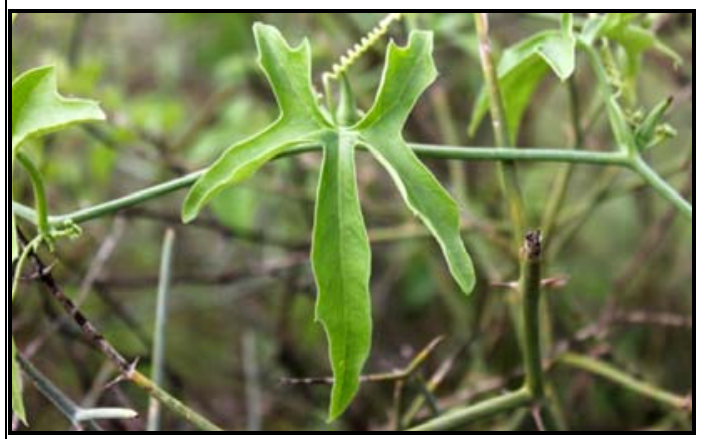

Corallocarpus conocarpus

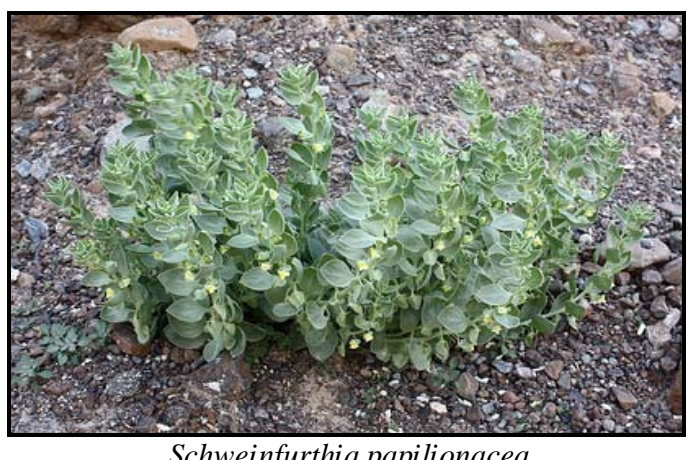

Schweinfurthia papilionacea

Plate 1. Less known rare and threatened plant species in Kachchh, Gujarat, India. 
observed in South West Africa, Angola and India. Earlier, Shah (1978) and Bhandari (1990) documented it from Gujarat. Bhandari and Singh (1964) also reported this plant from Kachchh region of Gujarat. In this study, the plant was located at four unprotected sites in Kachchh.

A total only 38 individuals were recorded from Kachchh (Gujarat). The overall density of the plant was 1.9/ha, and all were from unprotected areas, which exhibits that this species is very rare with sparsely distributed population. Moreover, from the above findings, it is apparent that the population is also severely fragmented.

The plant has been reported in flowering and fruiting phases during August to November (Hook, 1871). During our survey, the species was recorded in both the vegetative and reproductive stages. Leaves and flowering were observed in August, while fruiting was seen during August and September (Pl. 1).

D. welwitschii was associated with 6 species viz., Daemia extensa (33.33\%), Acacia leucophloea (20.00\%), Zizyphus mauritiana, Ipomoea pestigridis and Corallocarpus epigeus (13.33\% each) forming about $92.32 \%$ of the total association. Only one individual was found associated with Prosopis juliflora. It has been reported to climb on Euphorbia and Capparis spp. (Bhandari, 1990). In our survey, this species was observed on the agricultural hedges covered by dried thorny twigs and branches.

Hook (1871) has reported the occurrence of this species along the hedges of fields and gardens, and clumps of trees and shrubs. The present study showed that this species was found only along the agricultural hedges with sandy soils and sparse grasses. It has been reported that this species was mainly found on the edges of field interspersed with sandy loamy soils (Hook, 1871) and sandy gravelly soils (Bhandari, 1990). Among the different ecosystems visited, the plant was present only along the agricultural hedges. It was found to be associated with climbers and rarely with Prosopis juliflora. On the whole, this species was found along the agricultural hedges on gentle undulating terrain with sandy soil substrate with moderate soil depth.

A record of only 38 plants was not sufficient to identify the threats faced by this species. Also there are no reports and observations on the medicinal or economical significance of this species. It is just found along with the climbers along the agricultural hedges. A possible threat is habitat degradation for the individual found along with hedges devoid of cropland. As these hedges could be cut and be removed for fuel-wood purpose, such rare species also have chances to get eliminated from the natural habitats. The absence of regeneration of this species perhaps is of great concern. Studies on such aspects are warranted.

\section{Conservation measures recommended}

- Awareness programs on the occurrence and significance of such threatened species and its major role in biodiversity, should be directed towards the local community. Such steps would certainly be helpful to some extent to protect this species with the assistance of the local people.

- The individuals found besides the hedges without cultivation should be identified, and be protected with the help of local communities by recognizing such sites as Ecologically 
Sensitive Biodiversity Area (ESBAs). This could serve as a natural seed and gene bank to save its germplasm.

- Studies on the occurrence, distribution, habitat, phenology, seed viability and recruitment are very crucial.

- Seed collection to carry out germination studies and biotechnological studies are very necessary and of urgent need considering its highly restricted distribution and fragmented population.

- The species can be introduced in similar identical habitats inside the protected areas on a small-scale to study its success. Some individuals must be kept in Botanical and Experimental gardens to ensure its long-term survival in the in-situ and ex-situ conditions.

\section{Limonium stocksii (Boiss.) O. Ktze (Plumbaginaceae)}

It is a woody perennial undershrub (Shah, 1978) and also referred under the synonym Satice stocksii (Bole and Pathak, 1988). In Gujarat, it is locally known as Chitrak (Bole and Pathak, 1988). The species is found in Pakistan, Sind, Baluchistan and India. Only few authors have reported this plant from Gujarat, where this plant species is restricted only to Saurashtra and Kachchh regions. It is distributed in Bhiva, Veraval and Surashtra (Cooke, 1908), Dwarka, Okha Mandal, Jamnagar (Bole and Pathak, 1988), Bhadreshwar of Kachchh (Sabnis and Rao, 1983), Diu, Delvada, Navabandar (Menon, 1979) and in the coastal and saline soils of Mandvi (Menon, 1979; Sabnis and Rao, 1983).

In the present study, the plant was located at two sites in Kachchh viz., Bhadreshwar-Mundra and Lakhpat-Gunaeri. It was documented solely in the unprotected area. It flowers during winter months (Bole and Pathak, 1988) but in the present study flowering stage was observed during August and fruiting during August and September (Pl. 1). It reproduces by seed germination. The seed is carried by water during spring tide, and trapped alongwith other threatened grass species (Urochondra setulosus). On the whole, 20-30 seedlings were found to aggregate near the parent plants within a radius of half meter.

During the study period, L. stocksii was associated with 8 species of plants viz., Urochondra setulosus (25.60\%), Cyperus conglomeratus (25.26\%) and Aeluropus lagopoides (18.09\%). The associated species were dominated by grass species, which formed about $62.5 \%$. It was also found alone or associated with other halophytes (Cressa cretica, Suaeda nudiflora and Sesuvium sesuvioides).

In the present study, this species was predominantly found in the coastal salt encrusted wasteland and in the abandoned saltpans in the coastal marine ecosystem. It has been reported that this species is found on coastal and saline soils (Menon, 1979; Sabnis and Rao, 1983). Among the different ecosystems assessed, the plant was present only in the coastal saline area. Interestingly, it was mostly found associated with grass species. The plant was abundant in areas where the terrain was flat with no slope and predominantly on sandy soil with moderate depth. This species is exclusively sitespecific and found in patches in the coastal saline soils of Kachchh and Saurashtra. Population of the plant is restricted mainly due to its site-specific nature and less available favorable habitat.

In the present study, habitat destruction was the only threat observed. The plant is also endemic to Kachchh and Saurashtra regions. Moreover, it is highly site-specific 
and found only on saline wastelands with sandy soil, which makes the plant to occur in very limited locations. The habitat where the plant was located was severely affected by the construction of roads, conversion of saltpans, dockyard and settlements for salt workers.

Except for the ecological importance, there is no economic or medicinal value known. The plant as said could be effective indicator as salt resistant plant species. Status of the plant was earlier mentioned as common (Menon, 1979), rare (Sabnis and Rao, 1983) and intermediate (WCMC, 1996). No conservation measure has been undertaken till date.

\section{Conservation measures recommended}

- As the plant was exclusively observed at 2 sites in Mundra and Lakhpat Talukas of Kachchh district, such locations need immediate protection. The potential sites at Mundra must be identified for conservation.

- Developing nurseries close to such habitats to facilitate the better in-situ condition would enhance the survival capabilities of this species.

- The capacity to reproduce was found to be good during our study. The number of diminutive seedlings in the vicinity of the parent plant was considerably large. But the survival capabilities of these seedlings are unknown. Studies on the reproductive phenology of this plant are highly necessary to come out with proper conservation strategies.

- As the local people are unaware about this rare species, conserving this species in its natural habitat through the community participation would provide considerable protection.
- Studies on the microhabitat of $L$. stocksii, identifying similar habitats elsewhere and introducing the species in those environs should be encouraged as a part of a strategy for its long-term conservation.

\section{Schweinfurthia papilionacea (Linn.) Merrill (Scrophulariaceae)}

It is distributed in Afghanistan, Pakistan, Baluchistan, Sind, India (Gujarat) and NW Rajasthan (Cooke, 1967; Kirtikar and Basu, 1984; Bhandari, 1990). In Gujarat, Shah (1978) has reported this plant species to occur in Kachchh and Saurashtra Peninsula, while Rao (1981) and Sabnis and Rao (1983) reported it from Bhuj, Gandhidham, Anjar, Kandla and Khavda of Kachchh. Locally it is known as Sannipat or Sanipat (Shah, 1978; Bole and Pathak, 1988). In the present study, the plant was recorded only at single location near Bhachau in Kachchh district.

The reported flowering and fruiting season is October to December (Bhandari, 1990) and December (Shah, 1978). During the present study, vegetative, flowering and fruiting phases were noted from March to April. A total of 8 species were found to be associated with $S$. papilionacea. It was predominantly associated with Aristida $s p$. (39.53\%), followed by Fagonia schweinfurtii (24.42\%), Tridax procumbens (12.79\%), Convolvulus auricomus and Aerva javanica (8.14\% each). All these 5 species formed $93.02 \%$ of the associations.

$S$. papilionacea is reported to be present on rocky and gravelly soils (Sabnis and Rao, 1983). During the present study, the plant was documented from forest ecosystem predominantly with open scrub patches. It was found mostly on gentle slope 
with sparse grass cover and sandy loamy soil on a gravelly substrate. The plant species though recorded from open scrub forest close to human settlements and other developmental activities like roads and building construction, no visible threats could be identified. Only threat that could possibly have an impact was the digging for water pipeline. The plants were found just 5 $\mathrm{m}$ away from the pit, so there are chances that some individuals could have got destroyed by the digging. Proper monitoring is needed to identify the precise threat faced by the species (Pl. 1).

\section{Conservation measures recommended}

- Protection of natural habitats and introduction of this plant species into the Botanical or Experimental gardens should be done immediately. This would aid in preserving the seed and genes both in the in-situ and ex-situ conditions.

- Since the plants were present in a single patch near Bhachau area, immediate steps need to be taken by the Forest Department for protecting the species. This can be done by making a fence using Euphorbia nivulia line-hedge so as to save it from any type of impact which could lead to the local extinct of the species.

- A detailed study on the seed production and viability, germination and threats faced by the species is very essential to spell out proper strategies to substantiate the wild population.

- In-depth studies on the micro- and macro-habitats is very crucial, which is essential both in developing it in Botanical gardens and also form as a tool for identification of the reintroduction sites inside the protected areas.

- Since it is found close to human settlement, the locals should be made aware of its presence that would serve to reduce the threats posed by them knowingly and unknowingly. This would ensure the long-term survival of the species in the wild.

\section{Tribulus rajasthanensis Bhandari et} Sharma (Zygophyllaceae)

$T$. terrestris and $T$. rajasthanensis are closely related and distinguished by the bigger size of the flower, 2 median spines and absence of the lower pair of spines, 20 to $25 \mathrm{~cm}$ long and unequal minor spines and with terminating bristle from spines (Bhandari, 1990). Locally it is known as Sachu Gokharu.

Though this plant species name suggests that it is confined to Rajasthan region only, the species distribution extends upto south of Gujarat and westwards to Pakistan (Sind, Baluchistan and Sukkur), thus indicating the wide distribution of this species (Bhandari and Sharma, 1977). In India, it is confined to the drier regions of Rajasthan and Gujarat (Rao, 1981; Bhandari, 1990) mainly distributed in Ajmer, Jaisalmer, Jodhpur, Marwar, and Massuria in Rajasthan. In Gujarat, it is seen in Bhuj, Bhuj-Rodimaka, Jamnagar, Dwarka (Anon, 1982) and from Ningal and Bhuj (Rao, 1981).

In the present study, the plant species was documented from Kachchh district, from the maximum (72.7\%) locations. Most of the locations $(90.9 \%)$ were from areas without any protection, while only $4.6 \%$ were from protected areas. Based on the present study, the plant species was in 
Pankaj N. Joshi, Hiren B. Soni, S.F. Wesley Sunderraj and Justus Joshua/ Our Nature (2013), 11(2): 152-167

vegetative phase between August to November. Flowering was observed from May to November. Similarly, the fruiting phenophase was observed during the similar period (Pl. 1).

In total, 23 species were found to be associated with $T$. rajasthanensis. The major associates were Dactyloctenium sindicum (17.7\%), Aristida sp. (16.3\%), Cymbopogon martinii (15.7\%) and Solanum sp. (10.6\%) which formed $60.1 \%$ association. This would be helpful to identify the habitat of the species.

T. rajasthanensis was earlier reported to be available on rocky plateau and sandstone hills (Bhandari, 1990). In the present study, it was found in the dense or sparse grasslands with sandy soil but rarely found on gravels in Kachchh. The plant was documented from 6 ecosystems with the maximum abundance in grassland. They were found predominantly in the dense grassland, which were mostly on flat terrain with sandy and clayey substrate. It usually occurred in deep soil. The substrate recorded for this species was totally different from what was reported earlier.

Though during the survey no threats were observed, the grasslands being a preferred habitat for this plant species, and it is normally subjected to grazing pressure, it could be a probable threat to this plant.

\section{Conservation measures recommended}

- The Grasslands in Naliya must be declared as protected area, which would ensure protection to this species and also serve as natural seed and gene bank.

- An in-depth ecological study of the population variation, seed viability and germination is of importance.
- The plant could be introduced into the Botanical gardens for guaranteed protection as a part of ex-situ conservation.

\section{Conclusion}

The favourable climatic conditions, topography of terrains and landscapes, and diverse habitats and ecosystems of Kachchh, coupled with considerable protection have contributed to prevalence and concentration of rare and threatened plant taxa, which are remnants of the arid and semi-arid tracts of the region. However, in view of increasing anthropogenic pressures on land there is an urgent need to protect the impending areas to conserve regional and endemic plant diversity, not only for ecosystem health but also for the benefit of the indigenous tribes who heavily depend on local plant diversity for their dayto-day requirements. This may be possible by developing a network of protected sacred groves through tribal traditional institutions, since considerable number natural areas in Kachchh as well as Gujarat State is under the control of indigenous tribes.

\section{Acknowledgements}

Authors are thankful to Gujarat Institute of Desert Ecology (GUIDE) for providing necessary scientific guidelines to carry out this work. Thanks are also rendered to Mr. R.L. Meena, IFS, Chief Conservator of Forests, Kachchh Circle; Mr. L.N. Jadeja (Former DCF, West), Mr. D.T. Vasavada, (DCF, West), Mr. H.P. Waria (ACF), and Mr. M.B. Patel (RFO) (Kachchh West Division), Gujarat State Forest Department (GSFD), Bhuj, for providing permissions, logistic supports and manpower to carryout field works. 
Pankaj N. Joshi, Hiren B. Soni, S.F. Wesley Sunderraj and Justus Joshua/ Our Nature (2013), 11(2): 152-167

\section{References}

Anonymous 1982. Conservation supplement. Bulletin of Botanical Survey of India 24: 1-4.

Anonymous 1994. List of some vulnerable and endangered flowering taxa of India. Department of Agricultural Botany, Junagadh.

Barbour, M.G., J.H. Burk and W.D. Pitts 1987. Terrestrial Plant Ecology. Chapter 9: Method of Sampling the Plant Community. Benjamin/Cummings Pub. Co., Menlo Park, CA.

Bhanadri, M.M. and V.S. Sharma 1977. A new Tribulus (Zygophyllaceae) from India. Botaniska Notiser. 129: 367-369.

Bhandari, M.M and D. Singh 1964. Dactyliandra Hook. F., A cucurbitaceous genus new to Indian flora. Kew Bulletin 19: 133-138.

Bhandari, M.M. 1978. Flora of Indian Desert (Revised Ed.), MPS Reproduction House, Jodhpur. pp. 222-223.

Bhandari, M.M. 1990. Flora of Indian Desert (Revised Ed.), MPS Reproduction House, Jodhpur. pp. 83-84.

Bhandari, M.M., D.D. Kaushik and N.S. Shekhawat 1996. Rare, threatened and endangered plants of the Indian Desert-An action plan for their conservation. Final Consolidated Report, Submitted to Department of Biotechnology, Government of India, New Delhi. J.N. Vyas University, Jodhpur. 124p.

Bhatt, R.G. 1975. A contribution to the floristics and phytosociology of the Panchmahal Districts in Gujarat. Department of Botany, S.P. University, Vallabha Vidyanagar, Gujarat. (Ph.D. Thesis)

Blatter, E.J. 1908. On the flora of Cutch. J. Bombay Nat. Hist. Soc. 18: 756-777.

Blatter, E.J. and F. Hallberg 1918. Flora of Indian Desert. Scientific Publishers, Jodhpur. 13p.

Blatter, E.J. and F. Hallberg 1984. The Flora of Indian Desert. Scientific Publishers, Jodhpur. 160p.

Bole, P.V. and J.M. Pathak 1988. The Flora of Saurashtra (Part - II), Botanical Survey of India, Calcutta.

Contractor, G.J. 1986. Floristic, Phytosociological and Ethnobotanical study of Vapi and Umergoan Areas in South Gujarat. Department of Botany, South Gujarat University, Surat, Gujarat. (Ph.D. Thesis)

Cooke, T. 1908. Flora of the Presidency of Bombay (Vol. II). Botanical Survey of India, Calcutta. 324p.

Cooke, T. 1958. Flora of the Presidency of Bombay. Botanical Survey of India. Calcutta.
Cooke, T. 1967. Flora of the Presidency of Bombay. (Reprint Ed.) Botanical Survey of India. Calcutta.

FSI 2002. The Manual of Instructions for Field Inventory. Forest Survey of India, Dehradun. 128p.

Greig-Smith, P. 1964. Quantitative Plant Ecology. London, Butterworths. 154p.

Hill, D.A., M. Fasham, G. Tucker, M. Shewry and P. Shaw 2005. Handbook of Biodiversity Methods: Survey, Evaluation and Monitoring. Cambridge University Press, UK. pp. 219-222.

Hook, F. 1871. In Flora of Rajasthan (Eds. B.V. Shetty and V. Singh). Flora of India Series-2 (1987), Botanical Survey of India 2: 557.

Kalra, Y.P. and D.G. Maynard 1991. Methods: Manual for Forest Soil and Plant Analysis. Information Report NOR-X-319, Forestry Canada, Northwest Region, Northern Forestry Centre. Edmonton, AB, Canada.

Kirtikar, K.R. and B.D. Basu 1984. Indian Medicinal Plants. B. Singh and M.P. Singh, Dehra Dun. 249p.

Matthew, W.F. and R.T.F.M. Aller 1993. Methods for Plant Sampling. Restoration in the Colorado Desert: Management Notes. Prepared for the California Department of Transportation District 11, 2829 Juan Street, San Diego, CA, 92138.

Menon, A.R.R. 1979. Floristics and Phytosociological Studies of Some Parts of Saurashtra. Department of Botany, S.P. University, Vallabh Vidyanagar, Gujarat. (Ph.D. Thesis)

Nayar, M.P. and A.R.K. Shastry 1988. Red Data Book of Indian Plants. Botanical Survey of India, Calcutta. 148p.

Palin, C.T. 1880. A list of plants of Kutch. Bombay Gazetteer, Bombay.

Pandey, R.P., B.V. Shetty and S. Malhotra 1983. In Assessment of Threatened Plants of India (Eds. S.K. Jain and R.R. Rao). Botanical Survey of India, Howrah. 182p.

Patel, R.I. 1971. Forest flora of Gujarat State. Gujarat State Forest Department, Gujarat State, Baroda. 171p.

Phillips, E.A. 1959. Methods of Vegetation Study. University of Michigan Biological Station. HoltDryden Book, Henry Holt and Co., U.S.A. 105 p.

Puri, G.S., S.K. Mukherjee, S. Sarup and M.N. Kotwal 1964. Flora of Rajasthan. Records of Botanical Survey of India. 19: 1-159.

Rao, K.S.S. 1981. Studies on the Flora of South Eastern Kachchh. Department of Botany, M.S. 
Pankaj N. Joshi, Hiren B. Soni, S.F. Wesley Sunderraj and Justus Joshua/ Our Nature (2013), 11(2): 152-167

University of Baroda, Vadodara, Gujarat. 97p. (Ph.D. Thesis)

Sabnis, S.D. and K.S.S. Rao 1983. Rare and endangered endemics of South Eastern Kachchh. In Assessment of Threatened Plants of India (Eds. S.K. Jain and R.R. Rao), Botanical Survey of India. pp. 71-72.

Santapau, H. 1962. The flora of Saurashtra. Saurashtra Research Society, Rajkot, Gujarat. 362p.

Saxton, W.T. and L.J. Sedgwick 1918. Plants of Northern Gujarat. Records of Botanical Survey of India. 9: 251-262.

Shah, G.L. 1978. Flora of Gujarat State (Part - I and II). University Press, Sardar Patel University, Vidyanagar, Gujarat. 992p.

Shetty, B.V. and V. Singh 1988. Flora of Rajasthan (Vol. II). Botanical Survey of India. Calcutta. 198p.
Simpson,

E.H. 1949. Measurement

of Diversity. Nature 163: 688.

Thaker, J.I. 1926. Plants of Kutch and their utility. Saurashtra University Press, Rajkot, Gujarat. 406p.

Vashi, B.G. 1985. Floristic, Phytosociological and Ethnobotanical Study of Umarpada Forest in South Gujarat. Department of Botany, South Gujarat University, Surat, Gujarat. (Ph.D. Thesis)

WCMC 1996. Checklist of CITES Species. A reference to the appendices to the Convention on International Trade in Endangered Species of Wild Fauna and Flora. CITES Secretariat and World Conservation Monitoring Centre, Geneva, Switzerland and Cambridge, UK. 400p. 